\title{
MENINGKATKAN POTENSI USAHA MIKRO BERBASIS EKONOMI KREATIF BAGI ANGGOTA KOPERASI MELALUI PROGRAM PEMBERDAYAAN DAN PERAN KOPERASI SYARIAH (Studi Penelitian di Koperasi Syariah Tangerang Selatan)
}

\author{
Heri Nurranto, Askardiya Mirza Gayatri, Muzdalifah \\ Program Studi Pendidikan Ekonomi, \\ Fakultas Ilmu Pendidikan dan Pengetahuan Sosial, \\ Universitas Indraprasta PGRI \\ E-mail: heri.nurranto@gmail.com
}

Diterima: 02 September 2019; Direvisi: 11 November 2019; dipublikasikan: 13 Desember 2019

\begin{abstract}
This research aims to increase the potential of a micro-economy based creative economy through empowerment programs and the role of CMS Syariah Cooperatives with 92 members. This study uses a qualitative method. The data needed is primary and secondary data obtained from the chairman of the cooperative, the ranks of the cooperative management and members of the cooperative who have micro-businesses. The population of cooperative members who have micro-businesses is 9, all of which are sampled. Data collection through field observations, discussions, interviews, and documentation. The results showed that members of cooperatives that have micro-businesses really need creative economic knowledge, motivation, and coaching, including assistance in developing products and services so that they can contribute to CMS Cooperatives as a place for their businesses that will automatically turn on CMS Cooperative operations.
\end{abstract}

Keywords: Micro Business, Creative Economy, Empowerment Program

\begin{abstract}
ABSTRAK
Penelitian ini bertujuan untuk meningkatkan potensi usaha mikro berbasis ekonomi kreatif melalui program pemberdayaan dan peran Koperasi Syariah CMS yang jumlah anggotanya 92 orang. Penelitian ini menggunakan metode kualitatif. Data yang dibutuhkan adalah data primer dan sekunder yang diperoleh dari ketua koperasi, jajaran pengurus koperasi dan anggota koperasi yang mempunyai usaha mikro. Populasi anggota koperasi yang mempunyai usaha mikro berjumlah 9 orang yang seluruhnya dijadikan sampel. Pengumpulan data melalui observasi lapangan, diskusi, wawancara, dan dokumentasi. Hasil penelitian menunjukkan bahwa anggota koperasi yang mempunyai usaha mikro sangat memerlukan pengetahuan ekonomi kreatif, motivasi, dan pembinaan termasuk pendampingan dalam mengembangkan produk dan jasanya supaya bisa berkontribusi di Koperasi CMS sebagai wadah usahanya yang secara otomatis akan menghidupkan operasional Koperasi CMS.
\end{abstract}

Kata Kunci: Usaha Mikro, Ekonomi Kreatif, Program Pemberdayaan 


\section{PENDAHULUAN}

Keberadaan badan usaha non bank yang berbentuk koperasi diperkirakan akan terus meningkat sehingga perekonomian Indonesia akan lebih stabil karena peran koperasi menyasar ke semua pelosok desa sampai perkotaan, termasuk di dalamnya yaitu Koperasi Syariah. Peran Koperasi Syariah dalam menyalurkan dana salah satunya adalah untuk membiayai usaha mikro bagi para anggotanya atau yang sering disebut sebagai program Kredit Koperasi Primer Anggota (KPPA). Program KPPA yang dilaksanakan secara baik dan tepat sasaran dapat memberikan manfaat bagi anggota koperasi. Pada penelitian yang dilaksanakan oleh Dian Sari (2017) tentang evaluasi program KKPA PT Perkebunan Nusantara V di Kelurahan Sungai Pagar kabupaten Kampar menunjukkan bahwa program tersebut mampu memberikan beberapa dampak positif bagi anggota koperasi yaitu pertama, bahwa rata-rata anggota memiliki pendapatan kurang dari $\mathrm{Rp} 1.000 .000 /$ bulan sebelum ikut dalam program dan meningkat pendapatan mereka menjadi Rp. 1.500.000/bulan. Kedua, bahwa 74,63\% anggota koperasi menyatakan bahwa program KKPA PT. Perkebunan Nusantara V Kelurahan Sungai Pagar Kabupaten Kampar dapat memampukan anggota KUD Hidup Baru meningkatkan pendidikan anak mereka. Dampak yang terjadi ini membuat keefesienan anggota KUD hidup baru, sehingga mengurangi pengangguran, mengurangi banyaknya penduduk setempat yang mencari pekerjaan keluar daerah, dan membuat semakin berkualitasnya SDM masyarakat setempat karena dapat menyekolahkan anaknya (Sari, 2017).

Sejak tanggal 2 Februari 2011 pemerintah melalui kementerian Koperasi dan UMKM telah berupaya meningkatkan populasi wirausahawan di Indonesia melalui Gerakan Kewirausahaan Nasional atau yang disingkat GKN. Program tersebut meliputi penyelenggaraan seminar, pelatihan sampai program pinjaman tanpa bunga. Dikutip dari data Badan Pusat Statistik (BPS) bahwa pada tahun 2017 jumlah usaha mikro sebanyak 62.106.900 orang, usaha kecil 757.090 unit, usaha menengah 58.627 unit dan usaha besar 5.460 unit. Jumlah tersebut diperkirakan terus mengalami peningkatan maka diharapkan setiap koperasi mampu menjadi wadah kegiatan usaha mereka (anggota), sehingga kualitas usaha mikro dan kecil khususnya memiliki kualitas. Melalui konsep ini maka diharapkan tujuan koperasi yang mendasarkan pada nilai-nilai maupun prinsip-prinsip koperasi dapat tercapai secara optimal. Dalam menciptakan kualitas atau keberhasilan koperasi, salah satu faktor kunci adalah kontribusi atau partisipasi aktif para anggotanya dalam memajukan usaha koperasi, sehingga pasifnya anggota koperasi dapat memperlambat perkembangan operasional/kegiatan koperasi yang berdampak pada tingkat keberhasilan koperasi.

Sebagai soko guru perekonomian, maka koperasi harus mampu menjadi agen perubahan bagi industri rumahan atau usaha mikro yang cenderung memiliki berbagai karakter kelemahan. Usaha mikro menjadi bagian penting dalam kegiatan usaha rakyat, oleh karenanya usaha mikro membutuhkan uluran pengembangan bagi pihak-pihak tertentu, terutama koperasi. Menurut Undang-Undang Nomor 20 Tahun 2008, usaha mikro adalah usaha produktif milik orang perseorangan dan atau badan usaha perseorangan yang memenuhi kriteria Usaha Mikro sebagaimana diatur dalam Undang-Undang ini yang diuraikan pada Pasal 6 Ayat 1, yaitu 1) memiliki kekayaan bersih paling banyak Rp50.000.000,00 (lima puluh juta rupiah) tidak termasuk tanah dan bangunan tempat usaha; atau 2) memiliki hasil penjualan tahunan paling banyak Rp300.000.000,00 (tiga ratus juta rupiah).

Menurut Harsono (2014: 36), ciri-ciri usaha mikro adalah 1) jenis barang/ komoditi usahanya tidak selalu tetap, artinya sewaktu-waktu dapat berganti, 2) tempat usahanya tidak selalu menetap, sewaktu-waktu berpindah tempat, 3) belum melakukan administrasi keuangan meskipun dengan cara yang sederhana, dan tidak memisahkan keuangan keluarga dengan keuangan usaha, 4) sumber daya manusianya (pelaku usahanya) belum memiliki jiwa wirausaha yang memadai, 5) tingkat pendidikan rata-rata relative sangat rendah, 6) umumnya belum akses kepada perbankan, namun sebagian dari mereka sudah akses ke lembaga keuangan non bank, 7) 
umumnya tidak memiliki ijin usaha atau persyaratan legalitas lainnya termasuk NPWP. Sedangkan jika dilihat dari kriteria jumlah tenaga kerja untuk usaha mikro yaitu 1-4 orang, jadi karyawan atau tenaga kerja maksimal 5 (lima) orang.

Koperasi Syariah Citra Mandiri Sejahtera (CMS) adalah salah satu koperasi syariah di kota Tangerang Selatan. Jumlah anggota Koperasi Syariah Citra Mandiri saat ini sebanyak 92 orang, dimana mayoritas berpendidikan strata satu (S1). Berdasarkan hal tersebut, koperasi Koperasi Syariah Citra Mandiri pada dasarnya memiliki kekuatan internal kuat yang memungkinkan anggota dapat berkontribusi secara maksimal untuk memajukan Koperasi. Anggota koperasi yang mayoritas berpendidikan S1 memungkinkan telah didukung oleh tingkat pengetahuan yang cukup, sehingga pemikiran-pemikiran atau ide gagasan dari mereka dapat memberikan peran dalam mengembangkan koperasi di masa yang akan datang. Akan tetapi dalam observasi awal ditemukan bahwa sebagian besar anggota tidak memiliki perhatian yang cukup terhadap keberadaan Koperasi Syariah Citra Mandiri. Mereka cenderung "berjalan" sendiri-sendiri dalam kegiatan atau usaha sehari-hari masing-masing. Dampaknya bahwa koperasi tidak memiliki posisi yang kuat untuk mengembangkan kegiatan opersional koperasi apalagi sebagai payung usaha anggotanya.

Dari 92 (sembilan puluh dua) anggota terdapat 9 (sembilan) anggota yang memiliki usaha sendiri dan 83 (delapan puluh tiga) anggota lainnya berprofesi sebagai pegawai di suatu lembaga atau perusahaan. Komposisi anggota tersebut membuat Koperasi Syariah Citra Mandiri dituntut mampu memberdayakan anggota yang telah memiliki usaha sendiri secara optimal. Jika hal ini tidak dilakukan maka dikwatirkan koperasi tidak akan memiliki core competition koperasi sebagai wadah kegiatan usaha anggota. Keberhasilan membina anggota dalam usahanya akan menjadi daya tarik bagi anggota-anggota lain untuk mempunyai usaha sendiri khususnya bagi anggota yang belum memiliki pekerjaan tetap. Bagi anggota yang saat ini berprofesi menjadi pegawai/karyawan memungkinkan peran koperasi menjadi pertimbangan tersendiri bagi mereka untuk memiliki kegiatan/usaha sampingan bahkan alih profesi menjadi wirausaha di bawah binaan koperasi.

Peran Koperasi Syariah Citra Mandiri seyogyanya mampu meningkatkan pengetahuan dan keterampilan anggota dalam berwirausaha baik secara mandiri maupun mengadakan kemitraan dengan pihak lain, baik pemerintah, Lembaga Swadaya Masyarakat (LSM) maupun lembaga-lembaga pendidikan di sekitarnya. Hal ini didasarkan bahwa saat ini masih terdapat kecenderungan bahwa anggota koperasi yang memiliki usaha masih memiliki kekurangan pengetahuan dalam menjalankan usaha dengan benar dan tepat sasaran.

Penelitian yang dilakukan oleh Endaryono dan Djuhartono (2018) berjudul "Membangun Jaringan Pasar untuk Mengembangkan Usaha Produk Lokal Dalam Menumbuh Kembangkan Usaha Berbasis Sumber Daya Lokal Melalui Usaha Mikro dan Keuangan Mikro", memberikan acuan strategi pendampingan pada pengabdian masyarakat yaitu memberikan pengetahuan tentang pendidikan keuangan untuk "perempuan matang". Pendidikan itu diberikan berdasarkan kriteria masyarakat yang memiliki usaha produk lokal dengan rata-rata umur diatas 40 tahun, dimana materi yang diberikan berupa, membentuk prakoperasi, koperasi serta bagaimana membuat tabungan untuk masa depan. Penelitian yang kami laksanakan memberikan pengembangan strategi yang berbeda dalam meningkatkan potensi usaha mikro yang didasarkan pada masalah-masalah yang dihadapi oleh anggota Koperasi Syariah Citra Mandiri di lapangan.

\section{Ekonomi Kreatif dan Pemberdayaan}

Ekonomi kreatif menurut Kementerian Perdagangan Republik Indonesia (2008) didefinisikan sebagai wujud dari upaya mencari pembangunan yang berkelanjutan melalui kreativitas, yang mana pembangunan berkelanjutan adalah suatu iklim perekonomian yang berdaya saing dan memiliki cadangan sumber daya yang terbarukan. Ekonomi kreatif juga dapat dikatakan sebagai suatu sistem transaksi penawaran dan permintaan yang bersumber pada 
kegiatan ekonomi yang menggerakkan sektor industri yang disebut industri kreatif, jadi industri kreatif merupakan bagian dari ekonomi kreatif. Industri kreatif merupakan industri yang berasal dari pemanfaatan kreativitas, keterampilan serta bakat atau talenta individu yang menciptakan lapangan pekerjaan melalui daya cipta dan kreasi menjadi suatu produk barang atau jasa yang kreatif.

Dalam Peraturan Presiden Nomor 72 Tahun 2015, tentang Badan Ekonomi Kreatif bahwa produk ekonomi kreatif diklasifikasikan ke dalam 16 subsektor, yang diurutkan sesuai dengan urutan Klasifikasi Baku Lapangan Usaha Indonesia (KBLI) adalah 01) Arsitektur, 02) Desain Interior, 03) Desain Komunikasi Visual, 04) Desain Produk, 05) Film, Animasi, dan Video, 06) Fotografi, 07) Kriya, 08) Kuliner; 09) Musik, 10) Fesyen, 11) Aplikasi dan Game Developer, 12) Penerbitan, 13) Periklanan, 14) Televisi dan Radio, 15) Seni Pertunjukan dan 16) Seni Rupa (Putra, 2017, bekraf.go.id).

Saat ini di era digitalisasi, usaha mikro tidak lepas dari keterkaitannya dengan ekonomi kreatif, yang mana dalam pengembangan ekonomi kreatif di Indonesia diawali dari Instruksi Presiden Nomor 6 Tahun 2009 tentang Pengembangan Ekonomi Kreatif yang berhasil merumuskan Rencana Induk Pengembangan Ekonomi Kreatif Indonesia tahun 2009-2025 oleh Kementerian Perdagangan Republik Indonesia pada 2011 membentuk Kementerian Pariwisata dan Ekonomi Kreatif. Selanjutnya melalui Peraturan Presiden Nomor 6 Tahun 2015 terbentuk Badan Ekonomi Kreatif (Putra, 2017, bekraf.go.id).

Dalam rencana strategis Badan Ekonomi Kreatif 2015-2019 diuraikan menjadi 3 sasaran pokok yaitu: 1) kreativitas adalah kapasitas atau daya upaya untuk menghasilkan atau menciptakan sesuatu yang unik dan baru serta menciptakan solusi dari suatu masalah atau melakukan sesuatu yang berbeda; 2) ekonomi kreatif adalah penciptaan nilai tambah yang berbasis kreativitas; 3 ) usaha ekonomi kreatif adalah entitas usaha baik yang berbadan hukum maupun tidak berbadan hokum yang mentransformasikan dan memanfaatkan kreativitas untuk menghasilkan barang dan jasa serta yang diakui memiliki hak kekayaan intelektual baik terdaftar maupun melekat.

Keberadaan usaha mikro dan kecil membutuhkan perhatian khusus agar potensi mereka dapat optimal sebagai kegiatan ekonomi rakyat dalam memenuhi kebutuhan serta kuat dalam era saat ini. Selain pemerintah, peran dari pihak-pihak tertentu dibutuhkan sebagai upaya memberdayakan potensi usaha mikro dan kecil di masyarakat. Pemberdayaan masyarakat melalui membangun jaringan usaha mikro dan keuangan mikro, yakni dalam aspek reformasi, investasi pada usaha mikro maka perlu diberikan kebutuhan strategis melalui. a. Kebijakan nasional pengembangan keuangan mikro yang adil sebagai landasan filosofi dan platform bersama dalam mengembangkan produk lokal, usaha mikro, kecil dan menengah serta perkembangan kelompok masyarakat b. Kerangka hukum bagi lembaga keuangan mikro (LKM) dalam bentuk UU/PP atau paling tidak Perda sebagai payung legalitas LKM di daerah. c. Pelatihan bagi masyarakat untuk peningkatan kapasitas usaha produk lokal, usaha mikro dan menengah dalam hal, produk, pemasaran, akses kredit, membangun jaringan pasar dan lain lain d. adanya Forum Peduli masyarakat usaha kecil mikro yang dapat memberikan kontribusi positif yang saling menguntungkan baik (Endaryono dan Djuhartono, 2018).

\section{Koperasi Syariah dan Perannya}

Berawal dari lahirnya Bank Muamalat Indonesia (BMI) sebagai sentral perekonomian yang bernuansa Islam, maka bermunculan lembaga-lembaga keuangan yang lain yang ditandai dengan tingginya semangat bank konvensional untuk mendirikan lembaga keuangan Islam yaitu bank syari'ah (Sumiyanto, 2008:23). Tetapi karena operasionalisasi bank syari'ah di Indonesia kurang menjangkau usaha masyarakat kecil dan menengah, maka muncul usaha untuk mendirikan lembaga keuangan mikro seperti BPR syari'ah dan BMT yang bertujuan untuk mengatasi hambatan operasioanalisasi di daerah-daerah. Dalam perkembangannya, 
memunculkan jenis koperasi berbasis syariah atau disebut sebagai koperasi syariah. Koperasi Syariah yang didefinisikan sebagai adalah bentuk koperasi yang memiliki prinsip, tujuan, dan kegiatan usahanya berdasarkan syariah Islam, yaitu Al-quran dan Assunah. Berdasarkan Peraturan Menteri Koperasi dan Usaha Kecil dan Menengah Republik Indonesia Nomor 16/Per/M.KUKM/IX/2015 tentang Pelaksanaan Kegiatan Usaha Simpan Pinjam dan Pembiayaan Syariah oleh Koperasi memberikan pengertian bahwa Koperasi Simpan Pinjam dan Pembiayaan Syariah atau koperasi jasa keuangan syariah adalah koperasi yang kegiatan usahanya meliputi simpanan, pinjaman dan pembiayaan sesuai prinsip syariah, termasuk mengelola zakat, infaq/sedekah dan wakaf.

Tujuan pengembangan Koperasi Jasa Keuangan Syariah/Unit Jasa Keuangan Syariah adalah untuk 1) Meningkatkan program pemberdayaan ekonomi, khususnya di kalangan usaha mikro, kecil, menengah dan koperasi melalui sistem syariah 2) Mendorong kehidupan ekonomi syariah dalam kegiatan usaha mikro, kecil, dan menengah khususnya dan ekonomi Indonesia pada umumnya dan 3) Meningkatkan semangat dan peran serta anggota masyarakat dalam kegiatan Koperasi Jasa Keuangan Syariah (Sholihin, 2013: 459). Dalam menjalankan usahanya koperasi syariah memiliki beberapa landasan hukum yaitu 1) Peraturan Menteri Negara Koperasi dan Usaha Kecil Menengah No. 35.2/PER/MKUM/2007, Koperasi Syariah memiliki landasan dalam melakukan kegiatan usahanya, yaitu 2) Pancasila dan Undang-Undang Dasar Tahun 1945, 3) berlandaskan asas kekeluargaan dan 4) berlandaskan pada syariah Islam, yaitu Al-quram dan Ash-Shunah dengan saling tolong-menolong (ta'awun) dan saling menguatkan (takaful).

Pada Peraturan Menteri Koperasi dan Usaha Kecil Menengah No. 35.2/PER/MKUM/2007 tersebut juga diuraikan prinsip koperasi syariah yang dianut yaitu: 1) Kekayaan merupakan amanah dari Allah SWT dan tidak bisa dimiliki sepenuhnya oleh siapapun secara mutlak; 2) Setiap manusia berhak dan diberi kebebasan untuk bermu'amalah selama hal tersebut sesuai dengan ketentuan syariah; 3) Umat manusia adalah khalifah Allah dan pemakmur di muka bumi ini; 4) Menjunjung tinggi keadilan, serta menolak semua yang berhubungan dengan ribawi dan pemusatan sumber ekonomi pada sekelompok orang.

Keberadaan koperasi syariah tidak kalah pentingnya dengan koperasi kovensional, dimana fungsi koperasi syariah adalah untuk 1) Membangun dan mengembangkan segala potensi anggotanya secara khusus, serta meningkatkan kesejahteraan sosial ekonomi masyarakat pada umumnya, 2) Memperbaiki dan atau meningkatkan kualitas sumber daya manusia anggota untuk lebih amanah, profesional, konsisten dan konsekuen dalam menjalankan prinsip-prinsip ekonomi dalam syariah Islam, 3) Berupaya mewujudkan dan meningkatkan perekonomian nasional sebagai usaha bersama berdasarkan azas demokrasi dan kekeluargaan, 4) Menjadi sebuah wadah atau mediator yang dapat menghubungkan pemegang dana dengan pengguna dana sehingga pemanfaatan harta lebih optimal, 5) Berusaha untuk memperkuat setiap ekonomi anggota koperasi untuk saling bekerjasama dalam melakukan kontrol terhadap operasional koperasi, 6) Membuka dan memperluas lapangan pekerjaan bagi para anggota dan masyarakat secara luas dan 7) membantu menumbuhkan dan mengembangkan berbagai usaha produktif anggota koperasi.

Jika melihat beberapa kelemahan atau karakter usaha seperti yang diuraikan pada awal tulisan ini, maka anggota Koperasi Syariah CMS tergolong sebagai orang yang memiliki atau melaksanakan usaha mikro. Tujuan penelitian untuk meningkatkan potensi usaha mikro berbasis ekonomi kreatif melalui program pemberdayaan dan peran Koperasi Syariah CMS dalam menciptakan usaha rintisan atau pengembangan usaha dari anggota. Tujuan lainnya dari penelitian ini adalah memberikan pengetahuan serta masukan kepada anggota supaya dapat menyiapkan diri di era digitalisasi melalui usaha mikro berbasis ekonomi kreatif. Melalui langkah ini diharapkan ke depan, anggota Koperasi Syariah yang memiliki usaha telah siap 
bersaing secara sehat dan syar'i dengan pelaku usaha mikro yang lain dan memotivasi anggota supaya potensi kewirausahaannya tergali melalui kreativitas dan kemampuan yang dimilikinya.

\section{METODE}

Penelitian ini menggunakan metode kualitatif yang mendasarkan pada data primer dan sekunder. Data-data tersebut diperoleh dari informan-informan yang diambil dengan metode judgement, dimana peneliti memiliki kriteria tertentu dalam penentuan sampel informan. Adapun informan dalam penelitian ini adalah Ketua Koperasi, jajaran pengurus koperasi Syariah CMS serta anggota koperasi yang mempunyai usaha mikro. Sesuai dengan tujuan penelitian ini, maka sasaran penelitian ini adalah anggota koperasi CMS yang memiliki usaha, dimana dari anggota yang berjumlah 92 orang, terdapat 9 orang yang memiliki atau mejalankan usaha mikro, maka seluruh anggota yang memiliki usaha tersebut dijadikan sampel dalam penelitian ini.

Dalam penelitian kualitatif, pengumpulan data dapat diperoleh melalui diskusi, wawancara, observasi lapangan dan dokumentasi (Sugiyono, 2013:137). Desain penelitian ini diawali dengan pelaksanaan pada siklus 1 yaitu membentuk kelompok anggota koperasi yang mempunyai usaha mikro yang terbagi menjadi 3 (tiga) kelompok yang terdiri dari kelompok A (keripik, snack) sebanyak 3 orang, kelompok B (katering, lauk) 3 orang dan kelompok C (usaha jasa konveksi, kerajinan/ kriya, dan penitipan anak) 3 orang. Masing-masing kelompok diberikan lembar isian (kuesioner), setelah mengisi masing-masing kelompok mendiskusikan akan apa yang diisi yang tentunya jawabannya berbeda satu sama lain. Selama kegiatan berlangsung peneliti melakukan observasi untuk mengamati dan mencatat perilaku dan partisipasi anggota dalam kelompok. Hasil observasi peneliti selanjutnya dijadikan bahan/ materi untuk pelaksanaan pada siklus-siklus berikutnya. Tabel berikut adalah rincian dari setiap siklus sebagai dasar pemetaan tingkat pengetahuan dan permasalahan yang dihadapi oleh pelaku usaha mikro anggota Koperasi Syariah CMS Tangerang Selatan.

\section{Tabel 1}

Desain Penelitian

\begin{tabular}{|c|c|}
\hline Siklus Penelitian & Desain Penelitian \\
\hline \multirow[t]{5}{*}{ Siklus 1 Perencanaan } & 1) Observasi usaha mikro anggota. \\
\hline & 2) Identifikasi usaha mikro berbasis ekonomi kreatif \\
\hline & 3) Pembentukan kelompok \\
\hline & 4) Pemberian lembar isian \\
\hline & 5) Evaluasi \\
\hline \multirow[t]{5}{*}{ Siklus 2 Tindakan } & 1) Mendiskusikan hasil siklus 1 \\
\hline & 2) Observasi di lapanga \\
\hline & 3) Identifikasi hasil observasi di Lapangan \\
\hline & 4) Diskusi kelompok \\
\hline & 5) Evaluasi dan presentasi \\
\hline \multirow[t]{5}{*}{ Siklus 3 Pengamatan } & 1) Observasi indikator usaha mikro berbasis ekonomi kreatif \\
\hline & 2) Hasil laporan tugas kelompok (portofolio) \\
\hline & 3) Kelebihan dan kelemahan anggota dalam mengisi lembar isian \\
\hline & $\begin{array}{l}\text { 4) Evaluasi motivasi usaha mikro berbasis ekonomi kreatif } \\
\text { melalui wawancara }\end{array}$ \\
\hline & $\begin{array}{l}\text { 5) Refleksi hasil pemberdayaan anggota pada usaha mikro } \\
\text { berbasis ekonomi kreatif melalui peran Koperasi Syariah dalam } \\
\text { meningkatkan kesejahteraan anggota }\end{array}$ \\
\hline
\end{tabular}

Sumber : Data primer yang Telah diolah Penulis (2019) 


\section{HASIL DAN PEMBAHASAN}

Dari hasil survei pendahuluan dan berdasarkan teori-teori yang telah dikemukakan, peneliti menilai usaha mikro berbasis ekonomi kreatif di Koperasi Syariah CMS masih sangat rendah dan anggota belum memanfaatkan peran koperasi sebagai payung usaha secara maksimal. Berdasarkan hal ini maka, dibutuhkankan adanya strategi pemberdayaan bagi anggota koperasi baik yang sedang merintis usaha baru, mengembangkan usaha yang lama, atau anggota hanya menyimak saja karena belum termotivasi untuk berkontribusi pada usaha mikro berbasis ekonomi kreatif.

\section{Pemetaan Tingkat Pengetahuan Ekonomi Kreatif}

Era digitalisasi saat ini sangat memudahkan kita dalam mendapatkan semua informasi yang kita butuhkan. Walaupun begitu, bagi pelaku usaha mikro dan atau masyarakat tanpa adanya bimbingan atau sosialisasi dari pihak lain (misalnya, pemerintah) atas manfaat teknologi bahkan cara akses mendapatkan informasi, mereka tidak pernah dan termotivasi untuk menggunakan peran teknologi di era digital saat ini. Akibatnya, masih terdapat pelaku usaha mikro memiliki pengetahuan yang rendah baik secara umum maupun berkaitan dengan kebutuhan usahanya.

Dalam upaya memetakan tingkat pengetahuan pelaku usaha mikro pada anggota Koperasi Syariah CMS, diawali dengan memberikan lembar isian yang dikerjakan secara berkelompok bertujuan untuk saling sharing antar anggota. Hal ini bertujuan untuk memberikan pemahaman bahwa dalam wadah koperasi salah satunya melakukan kegiatan secara bersama-sama dan kelak dinikmati secara bersama pula. Dalam lembar isian tersebut anggota akan melakukan diskusi dalam kelompok kecil untuk mengemukakan pendapat/ ide/ gagasan/ opini dan sebagainya serta akan saling bekerja sama pada tugas yang diberikan oleh peneliti. Proses pemetaan pengetahuan ekonomi kreatif ini dilakukan melalui 3 (tiga) siklus, dimana tujuan akhir dari pelaksanaan siklus 1 sampai siklus 3 adalah untuk mendapatkan asumsi yang mendasar untuk memberikan solusi strategi pemberdayaan usaha mikro berbasis ekonomi kreatif melalui peran koperasi Syariah dalam meningkatkan potensinya.

Dari 9 (sembilan) orang anggota Koperasi Syariah CMS yang mempunyai usaha mikro, diperoleh karateristik dasar responden yaitu anggota yang memiliki latar belakang pendidikan S2 sebanyak 3 (tiga) orang, S1 sebanyak 4 orang, dan SLTA/ SMK sebanyak 2 orang. Seluruh anggota tersebut telah memiliki rumah sendiri selama 5 s.d 10 tahun. Di lihat dari profesi/pekerjaan mereka memiliki pekerjaan utama yaitu sebagai sebagai pengajar 2 (dua) orang, ibu rumah tangga 4 (empat) orang dan 3 (tiga) lainnya adalah sebagai wiraswasta.

Hasil penelitian melalui desain siklus, bahwa pada pelaksanaan siklus 1, peneliti kesulitan dalam memberikan pemahaman akan pelaksanaan penelitian ini kepada anggota koperasi yang mempunyai usaha mikro dalam bidang kuliner terutama pada tim katering. Awalnya mereka mengira bahwa kami akan mengorek keuntungan usaha mereka dan omzet untuk keperluan pajak penghasilan. Melalui pendekatan dialog dengan menyampaikan secara terbuka tentang maksud dan tujuan penelitian ini yaitu untuk mendapatkan strategi pemberdayaan usaha mikro berbasis ekonomi kreatif, maka pelaksanaan yang sebelumnya kurang kooperatif menjadi kooperatif. Dalam proses selanjutnya, peserta peserta mengisi lembar isian tentang identitas diri, usaha mikro, pemberdayaan, ekonomi kreatif, dan kesejahteraan anggota dengan maksud untuk mendapatkan data awal sebagai bagian dari karakteristik responden.

Hasil pada siklus ini menunjukkan bahwa dari 9 (sembilan) anggota koperasi yang mempunyai usaha mikro hanya terdapat 1 (satu) orang yang mengetahui maksud dari pemberdayaan. Sehingga peneliti beranggapan bahwa semua peserta memerlukan pelatihan dan pengembangan diri, kesulitan mendapatkan tenaga kerja, kesulitan memasarkan produk. Selanjutnya dapat diketahui bahwa 2 (dua) orang telah aktif menggunakan media sosial. Dari 
siklus ini juga dapat diketahui bahwa semua pelaku usaha mikro anggota Koperasi Syariah CMS belum pernah ikut bazar atau buka stand untuk memasarkan produk-produk yang mereka hasilkan.

Pada kelompok B (usaha bidang catering dan lauk) masih harus banyak belajar tentang pengetahuan dalam berwirausaha seperti manajemen produksi, pengembangan produk dalam hal kreativitas dan inovasi produk dan pelaksanaan pemasaran. Sedangkan data dari Kelompok A (usaha produk keripik dan snack) dan Kelompok C (usaha jasa konveksi dan penitipan anak), menunjukkan bahwa pelaku usaha khususnya usaha konveksi sudah memahami manajemen produksi, namun belum bisa mengembangkan produk karena tidak ada keberanian dan takut gagal dalam usaha atau ketakutan terhadap dampak kerugian. Pada pelaku usaha penitipan anak pada umumnya sudah mengetahui manajemen dan melihat peluang pasar, namun juga masih mereka juga masih memiliki kekhawatiran dalam mengembangkan kreativitas dan inovasi usahanya.

Selanjutnya dilakukan evaluasi yang berkaitan dengan jawaban dari lembar isian, observasi dalam penelitian ini memberikan tugas untuk menghadiri dan mengamati pameran INACRAFT di Balai Sidang JCC (International Handicraft Trade Fair) Senayan yang diselenggarakan dari 24 s.d 28 April 2019, yang mengusung tema "Jakarta Enjoyable Multicultural Diversities".

Hasil pengamatan nantinya akan disampaikan dalam bentuk presentasi tanpa teks. Namun pada kenyataannya mereka hanya datang dan belanja saja serta hanya sekilas melihat-lihat yang bukan bidang usahanya, seperti anggota kelompok B (katering, lauk) lebih banyak atau menyukai stand kerajinan. Hasil evaluasi kelompok B bahwa, kelompok tersebut sangat menyukai hadir ke INACRAFT meskipun tugas yang peneliti berikan tidak dilaksanakan dengan baik.

Siklus 2 merupakan kegiatan yang mendiskusikan hasil siklus 1. Metode diskusi ini dipilih karena dianggap sebagai metode yang lebih efektif. Metode diskusi menurut Darwyan (2009: 143) yaitu percakapan yang responsif yang dijalin oleh pertanyaan-pertanyaan problematis dan diarahkan untuk memperoleh pemecahan masalahnya. Berdasarkan hasil pada siklus 1 bahwa tugas yang diberikan untuk menghadiri INACRAFT belum terlaksana dengan baik, maka peneliti memberikan tugas untuk menghadiri pameran produk binaan Bank Indonesia di JCC Hall A, dari tanggal 12 sampai dengan 14 Juli 2019. Pada siklus ini peneliti mengamati para anggota koperasi pelaku usaha mikro sudah memperlihatkan kemajuan karena telah mendapatkan pengalaman nyata dan menyenangkan atas keikutsertaan mereka dalam evnt pameran produk di JCC Jakarta.

Dari hasil laporan yang dipaparkan oleh masing-masing kelompok, presentasi tentang kewirausahaan yang mereka paparkan masih harus diperbaiki, baik dari cara berbicara maupun bersikap di depan umum. Maka melalui pendekatan interaktif dalam proses evaluasi, mereka sanggup untuk memperbaiki dengan cara presentasi lagi. Akibatnya, Siklus ini memakan waktu yang lama tidak sesuai dengan target rencana. Pada siklus 2 dilaksanakan 2x pertemuan karena kekurangan waktu pada saat diskusi kelompok sehingga kelompok B belum sempat presentasi hasil diskusi kelompok.

Dari topik/ tema diskusi bahwa peserta masih kurang mengerti dan memahami pada saat mengisi lembar isian (kuesioner) seperti yang berkaitan dengan 1) pemberdayaan; 2) pemasaran; 3) kreativitas dan inovasi produk; 4) sumber daya (bahan baku, tenaga kerja); 5) gelar produk; 6) modal; dan 7) peran koperasi. Setelah masing-masing kelompok melakukan diskusi pada tema-tema tersebut kemudian dilanjutkan dengan presentasi. Peserta diperkenankan untuk menggunakan media internet, dengan tujuan bahwa penggunaan internet selain untuk menambah pengetahuan juga bisa digunakan secara produktif berkaitan dengan usaha yang dijalankan. Setelah peneliti melakukan evaluasi hasil diskusi dan presentasi yang 
berupa tanya jawab, setelah peserta mendapatkan masukan-masukan dari peneliti maka hasil akhir dan atau perbaikan akan dibahas pada saat pelaksanaan siklus 3 .

Siklus 3 merupakan hasil laporan tiap kelompok berupa portofolio secara singkat . Dari siklus ini bahwa kelompok A masih memerlukan motivasi dan pengembangan diri sehingga masih dibutuhkan pelatihan-pelatihan atau praktek langsung untuk menggali kreativitas mereka. Peneliti memberikan masukan agar mereka mencoba menambah varian supaya tidak ketergantungan terhadap bahan baku. Akan tetapi mereka mengaku bahwa kesulitan mendapatkan tenaga kerja dan akses pemasaran sehingga memerlukan bantuan pemasaran. Seperti halnya kelompok A, pada kelompok B juga masih membutuhkan pelatihan dan praktek langsung dalam menentukan harga jual dan membuat laporan keuangan. Kelompok ini juga memiliki beberapa hambatan yaitu kesulitan mendapatkan tenaga kerja, kesulitan memasarkan produk karena usaha ini sangat menjamur. Sehingga pada kelompok B dapat diambil kesimpulan bahwa mereka membutuhkan kemitraan untuk memperkuat usaha mereka.

Seiring dengan kelompok A maupun kelompok B, bahwa kelompok C juga memiliki kesulitan dalam mendapatkan tenaga kerja terdidik. Kelompok $\mathrm{C}$ memerlukan motivasi untuk lebih kreatif. Minimnya kreatifitas dalam usaha bidang yang dilakukan oleh kelompok C, dapat berdampak pada kerugian dan tidak mampu melanjutkan usahanya kembali. Pada kelompok $\mathrm{C}$, mereka tidak mengetahui atau memahami bagaimana cara memasarkan jasa usahanya dengan tepat. Dalam pendekatan interaktif yang dilakukan, maka kelompok $\mathrm{C}$ menginginkan agar Koperasi Syariah CMS ikut berperan dalam mengembangkan usahanya. Hasil dari siklus penelitian yang telah diuraikan di atas secara terperinci ditunjukkan pada tabel berikut.

Tabel 2

Hasil Siklus Desain Penelitian

Siklus Penelitian Deskripsi Hasil

1) Pada awalnya pelaku usaha tidak kooperatif

2) Diperoleh deskripsi responden

Siklus 1 Perencanaan 3) Dibentuk 3 (tiga) kelompok berdasarkan bidang usaha

4) Peserta kesulitan dalam mengisi lembar kuesioner

5) Pelaku usaha mikro anggota Kopsyah CMS masih rendah dan menghadapi kendala usaha

1) Diskusi interaktif

2) Peserta tidak mampu melaporkan studi banding/pameran sehingga dilakukan studi banding/mengunjungi pameran ke-2

Siklus 2 Tindakan

3) Terdapat peningkatan pengetahuan tetapi belum mempu membuat laporan dengan baik

4) Diskusi peserta menghasilkan kesepakatan untuk memperbaiki laporan dan presentasi

5) Menambah waktu diskusi dan presentasi karena banyaknya perbaikan presentasi

1) Observasi indikator ekonomi kreatif : pemberdayaan, pemasaran, kreativitas dan inovasi produk, sumber daya (bahan baku, tenaga kerja), gelar produk, modal dan peran koperasi

2) Peserta kesulitan dalam mendapatkan tenaga kerja, akses pemasaran, ketergantungan bahan baku dan kreatifitas

Siklus 3 Pengamatan

3) Peserta memiliki pengetahuan dan pemahaman yang kurang dalam indikator ekonomi kreatif

4) Peserta masih butuh motivasi dalam keuletan dalam menjalankan usaha 
5) Refleksi strategi : a) Tenaga kerja : rekrut siswa SMK dan pembetrdayaan remaja, ibu-ibu dan kaum disabilitas b) Bahan baku : inovasi dan kreatifitas, c) motivasi dan pengembangan SDM, d) pelatihan peneytapan harga jual dan laporan e) peran Koperasi Syariah CMS

Sumber : Data primer yang Telah diolah Penulis (2019)

Berdasarkan permasalahan atau keadaan yang dialami oleh pelaku usaha mikro anggota Koperasi Syariuah CMS, maka diperlukan strategi-strategi khusus bagaimana peran koperasi mampu mendorong dan memberdayakan anggotanya dalam upaya mencapai keberhasilan usaha.

\section{Strategi Koperasi Syariah CMS dalam Pemberdayaan Usaha Mikro}

Semua pelaku usaha yang terbagi dalam 3 (tiga) kelompok memiliki banyak kesamaan yang membuat usahanya terhambat. Berdasarkan pada keadaan tersebut, maka penelitian ini melakukan proyeksi strategi yang dapat dilakukan dalam mengembangkan usaha mikro anggota koperasi CMS maupun secara general dapat digunakan oleh tanggota lain atau masyarakat pelaku usaha mikro secara umum. Adapun beberapa strategi Koperasi CMS untuk mengembangkan usaha mikro anggotanya adalah:

1. Masalah kesulitan tenaga kerja,

Kesulitan tenaga kerja merupakan masalah yang dihadapi oleh seluruh pelaku usaha mikro anggota Koperasi Syariah CMS. Masalah ini dapat diatasi dengan merekrut dan atau bekerjasama dengan siswa SMK jurusan tata boga untuk kuliner dan tata busana untuk jasa konveksi. Keterbatasan dana atau modal untuk membayar upah kepada pegawai, pelaku usaha dapat memilih opsi tenaga kerja magang atau kontrak. Hal ini dilakukan selain untuk mengantisipasi keterbatasan dana juga untuk menjaring pekerja yang sesuai dengan kemampuan yang dibutuhkan dalam usahanya. Koperasi sebagai wadah kegiatan ekonomi anggota dapat berperan sebagai perantara dan media komunikasi kemitraan dengan pihak SMK atau sekolah-sekolah di sekitar daerahnya. Selain siswa SMK koperasi dapat menjadi agen pemberdayaan terhadap ibu-ibu rumah tangga, remaja putus sekolah, atau kaum disabilitas.

2. Kesulitan bahan baku

Dalam mengatasi kesulitan bahan baku, pelaku usah mikro dapat mengembangkan produk berbasis inovasi dengan mengganti bahan baku lain. Jika bahan baku yang digunakan biasanya tidak bisa dihindari, maka pelaku usaha harus dapat memaksimalkan penggunaannya secra efektif dan efisien. Kemitraan dengan para pengusaha atau pengrajin lain dalam supply bahan baku bisa dilakukan, baik di daerah tersebut atau daerah lainnya. Berkaitan dengan hal ini, maka koperasi sebagai wadah usaha bisa memberikan akses kerjasama kemitraan dengan penyedia bahan baku. Pengembangan produk inovasi adalah bagian penting dalam mengatasi kelangkaan bahan baku, sehingga inovasi dan kreatifitas diharapkan dapat melahirkan karya produk unggulan atau produk substitusi yang dapat ditawarkan ke pasar atau pelanggan.

3. Motivasi dan pengembangan diri

Motivasi merupakan bagian paling mendasar dalam melakukan kegiatan usaha. Seseorang yang memiliki motivasi tinggi dalam menjalankan usaha akan berdampak pada penyelesaian masalah secara mandiri. Motivasi dapat dibangun dengan mengikuti pelatihan, seminar, workshop dan sharing informasi kepada pihak lain. Motivasi harus dibangun secara berkelanjutan untuk menciptakan kepercayaan diri yang kuat, baik saat usaha telah berhasil maupun saat usaha mengalami kerugian. Bahwa dalam motivasi perlu peran pihak 


\section{sosio e-kons}

Volume 11, No. 3, Desember 2019, pp. 204-216

e-ISSN: $2502-5449$

p-ISSN: 2085-2266

DOI : 10.30998/sosioekons.v11i3.4612

lain, Koperasi Syariah CMS seyogyanya mampu memberikan motivasi usaha dengan cara memberikan langkah konkrit, misalnya memberikan akses pasar, support peralatan, informasi maupun dana pinjaman lunak. Menurut Ariwibowo (2013), untuk memungkinkan peningkatan kemampuan UMKM dalam memanfaatkan peluang lokal dan pasar global perlu didukung dengan pengembangan lembaga pendamping atau yang lazim dikenal dengan Business Development Service (BDS). BDS ini diharapkan mampu menyediakan dukungan perkuatan untuk meningkatkan kemampuan UMKM dalam memperoleh akses teknologi dan pasar (non financial BDS) maupun akses terhadap permodalan (financial BDS).

4. Penetapan Harga Jual dan Laporan Keuangan

Penetapan harga jual merupakan bagian penting baik sebelum produk diproduksi maupun saat diluncurkan. Untuk merangsang daya tarik bagi pelanggan, khususnya bagi pengusaha baru, penetapan harga rendah merupakan strategi yang tepat untuk melakukan penetrasi pasar. Harga rendah yang dimaksud adalah tetap mengacu pada Return of Invesment (ROI). Pelaku usaha dapat menetapkan harga di bawah pasar dalam beberapa waktu atau periode untuk mendapatkan market share secara bertahap. Kelemahan pelaku usaha mikro pada umumnya adalah ketidaktertiban terhadap laporan kinerja keuangan. Kecenderungannya adalah hasil penjualan atau uang tidak dipisahkan dengan uang kebutuhan sehari-hari. Dalam tahap awal, Koperasi dapat memberikan sosialisasi atau pelatihan bagaimana membuat laporan keuangan yang praktis dan mudah. Target pertama yang harus ditekankan adalah tertib administrasi, sehingga secara bertahap kualitas laporan keuangan dapat ditingkatkan dan lebih sempurna diwaktu yang akan datang. Baik cara menetapkan harga jual maupun laporan keuangan dibutuhkan pelatihan yang teratur, terstruktur dan berkelanjutan serta pendampingan.

5. Event Edukatif

Dalam meningkatkan pengetahuan maupun ketrampilan anggota dalam menjalankan usaha, Koperasi Syariah CMS dapat melakukan secara teratur pertemuan-pertemauan dengan anggota. Pertemuan ini dapat dilakukan 1 kali dalam sepekan atau 2 kali dalam sebulan. Pertemuan sosialisasi dan edukatif yang teratur serta dalam intensitas yang seimbang dapat memberikan motivasi dan peningkatan pengetahuan kepada anggota dengan baik. Koperasi dapat melakukan kerjasama dan atau mendatangkan para ahli, praktisi, dosen ataupun guru serta motivator dan lain sebagainya. Hal ini dilakukan agar pengetahuan yang dimiliki anggota lebih banyak dan dalam aspek ilmu yang lebih luas. Secara singkat, bahwa dibutuhkan kemitraan edukasi bagi pelaku usaha mikro terhadap anggota Koperasi Syariah CMS, sehingga koperasi selayaknya bertindak sebagai wadah edukasi yang terstruktur untuk meningkatkan keberhasilan usaha ekonomi yang dijalankan oleh anggotanya.

Kelemahan-kelemahan yang dialami oleh anggota Koperasi Syariah CMS yang memiliki usaha mikro merupakan kelemahan yang umum ditemui di lapangan. Hal ini sejalan dengan penelitian yang dilakukan oleh Machmud Amir (2012) membuktikan bahwa UMKM masih menghadapi masalah yang mendasar yang salah satunya adalah masih kesulitan dalam mengakses UMKM pada pasar atas dari produk yang dihasilkan. Perbedaan dari penelitian ini adalah bahwa, pada penelitian ini objek bukan UMKM tetapi Usaha Mikro dari anggota Koperasi CMS dan bukan untuk mengentaskan kemiskinan tetapi mendapatkan strategi pemberdayaan usaha mikro.

Hasil dari penelitian yang lainnya yaitu Isa Muzakar (2016) menyimpulkan bahwa pengembangan industri kreatif yang merupakan bagian dari ekonomi kreatif melibatkan peran berbagai elemen seperti pemerintah, lembaga keuangan, asosiasi, mass media, agen, serta lembaga pendidikan dan pelatihan. Perbedaan dengan penelitian ini adalah jumlah populasi 


\section{sosio e-kons}

Volume 11, No. 3, Desember 2019, pp. 204-216

e-ISSN: $2502-5449$

p-ISSN: 2085-2266

DOI : 10.30998/sosioekons.v11i3.4612

yang masih minim dan strategi pemberdayaan yang diperlukan anggota koperasi CMS melalui peran koperasi dalam meningkatkan kesejahteraan anggota.

Sementara jika dilihat dari keterkaitan hasil penelitian dengan sumber dari teori-teori yang ada seperti yang telah diuraikan pada bagian awal tulisan ini, yang menyatakan pada tingkat pendidikan yang rendah maka pada kenyataannya anggota koperasi CMS yang kami jadikan responden dan informan pendidikan terendah SLTA/ SMK sebanyak 2 orang, S2 sebanyak 2 orang, sisanya 5 orang pendidikan S1. Sehingga pendidikan yang cukup tinggi juga memiliki keterbatasan pengetahuan, ketrampilan serta membutuhkan faktor lain agar mereka berhasil dalam usahanya, misalnya dengan mengikuti pameran, pelatihan atau pendampingan serta motivasi. Hasil observasi menunjukkan bahwa anggota Koperasi Syariah CMS yang memiliki usaha mikro, mereka masih sebatas ikut-ikutan dan belum menggali potensi atau talenta masing-masing individu sehingga perkembangan usahanya masih lambat dan produknya belum masuk kategori kreatif maupun inovatif.

Peran koperasi syariah belum dimaksimalkan oleh para anggota, meskipun pada saat RAT maupun pertemuan non formal diadakan, namun masih membutuhkan motivasi supaya potensi yang dipunyai bisa tergali secara maksimal, secara tidak langsung peran koperasi belum seutuhnya mensejahterakan para anggotanya terutama yang sudah mempunyai usaha mikro, bagi yang belum mempunyai usaha apabila mempunyai bakat atau potensi dalam berwirausaha dalam bidang apapun bisa dikembangkan melalui koperasi dengan cara menjual produk atau jasanya melalui koperasi.

\section{SIMPULAN DAN SARAN}

Berdasarkan hasil penelitian yang telah dilkaksanakan pada pelaku usaha mikro anggota

Koperasi Syariah CMS ndi Tangerang Selatan, dapat disimpulkan bahwa:

1. Tingkat partisipasi anggotanya masih sangat kurang sehingga secara tidak langsung akan menjadikan hambatan bagi koperasi CMS

2. Memerlukan program pemberdayaan ekonomi kreatif bagi anggota koperasi baik yang sudahmempunyai usaha maupun akan memulai usahanya.

3. Kesulitan dalam mendapatkan tenaga kerja sehingga usaha yang dijalankan tidak atau kurang maksimal.

4. Koperasi CMS untuk lebih sering memotivasi para anggotanya supaya aktif dalam semua kegiatan yang diadakan oleh koperasi CMS maupun dari koperasi lain.

5. Pengurus koperasi dan Pembina sudah saatnya melakukan secara aktif dalam mensosialisasikan program-program dari pemerintah tentang pemberdayaan yang berkelanjutan.

6. Dalam upaya memberikan pemahaman dan menambah pengalaman berwirausaha Koperasi Syariah CMS sebaiknya mendorong anggotanya untuk mengunjungi dan atau mengikuti pameran / festival/ bazar dan sebagainya supaya mendapatkan inspirasi dan pertemanan.

\section{UCAPAN TERIMA KASIH}

Kepada LPPM Universitas Indraprasta PGRI yang telah membantu mendanai dalam pelaksanaan penelitian ini melalui Surat Perjanjian Pelaksanaan Tugas Penelitian Semester Genap Tahun 2019 Nomor: 0367/SP3/KP/LPPM/UNINDRA/III/2019; Kepada Ibu Wardah Jafar. L.c,. M.Ag. selaku Ketua Koperasi Syariah CMS di Tangerang Selatan beserta pengurus yang berkenan memberi waktu dan data-data yang kami perlukan. 


\section{DAFTAR RUJUKAN}

Ariwibowo, Prasetio. Strategi Pemberdayaan Usaha Mikro Kecil dan Menengah (UMKM) Dalam Pengetnasan Kemiskinan dan Pembangunan Perekonomian di Indonesia. Journal of Applied Business and Economic Volume 1 No. 3, 2015, hal 173-183. DOI: https://journal.lppmunindra.ac.id/index.php/JABE/article/view/1398

Endaryono, Tony Bakti dan Djuhartono, Tjipto. 2018. Membangun Jaringan Pasar untuk Mengembangkan Usaha Produk Lokal Dalam Menumbuh Kembangkan Usaha Berbasis Sumber Daya Lokal Melalui Usaha Mikro dan Keuangan Mikro. Jurnal Sosio E-Kons, Volume 10, No. 3, Desember 2018, hal 228-233, DOI: https://journal.lppmunindra.ac.id/index.php/sosio_ekons/article/view/2793.

Harsono, Budi. 2014. Tiap Orang Bisa Menjadi Pengusaha Sukses Dan Kelas Dunia Melalui UMKM. Jakarta: PT Elex Media Komputindo.

Isa, Muzakar. 2016. Model Penguatan Kelembagaan Industri Kreatif Kuliner Sebagai Upaya Pengembangan Ekonomi Daerah. Prosiding Seminar Nasional Ekonomi dan Bisnis \& Call For Paper FEB UMSIDA 2016. DOI: http://eprints.umsida.ac.id/133/

Machmud, Amir. 2013. Strategi Pemberdayaan Usaha Mikro Kecil Menengah Melalui Peran Lembaga Keuangan Syariah Dalam Upaya Pengentasan Kemiskinan di Indonesia. Prosiding Seminar Nasional Fakultas Ekonomi Universitas Terbuka Tahun 2012, Tangerang Selatan. DOI: https://repository.ut.ac.id/5078/.

Peraturan Menteri Negara Koperasi dan Usaha Kecil Menengah No. 35.2/PER/MKUM/2007, tentang Pedoman Standar Operasional Manajemen Koperasi Jasa Keuangan Syariah.

Peraturan Menteri Koperasi dan Usaha Kecil dan Menengah Republik Indonesia Nomor 16/Per/M.KUKM/IX/2015.

Putra, Nadia Cifra. 2017. Rencana Strategis Badan Ekonomi Kreatif 2015 - 2019. DOI: https://www.bekraf.go.id/berita/page/17/rencana-strategis-badan-ekonomi-kreatif-20152019.

Sari, Dian. 2017. Evaluasi Program Kredit Koperasi Primer Anggota (KKPA) PT. Perkebunan Nusantara V. Sosio E-Kons, Volume 9 No 1 April 2017, hal. 9-17. DOI: https://journal.lppmunindra.ac.id/index.php/sosio_ekons/article/view/1683/1300.

Sholihin, Ahmad Ifham, Ahmad Ifham. 2013. Pedoman Umum Lembaga Keuangan Syariah. Jakarta : Gramedia.

Sugiyono. 2013. Metode Penelitian Kuantitatif Kualitatif Dan $R \& D$. Bandung: Alfabet.

Sumiyanto, Ahmad. 2008. Menuju Koperasi Modern : Panduan untuk Pemilik, Pengelola dan Pemerhati Baitul maal wat Tamwii dalam format Koperasi. Yogyakarta: Debeta.

Syah, Darwyan. dkk. 2009. Strategi Belajar Mengajar. Jakarta: Diadit Media. 